\title{
Kajian Pasar Modal Syariah Dalam Mempengaruhi Pertumbuhan Ekonomi di Indonesia
}

\author{
Marlina Widiyanti ${ }^{1 *}$ dan Novita Sari ${ }^{2}$ \\ ${ }^{1}$ Dosen Fakultas Ekonomi Universitas Sriwijaya \\ Jl. Palembang Kabupaten Ogan Ilir, Indralaya Indah, Indralaya, \\ Kota Prabumulih, Sumatera Selatan 30862 \\ ${ }^{2}$ Alumni Pascasarjana Fakultas Ekonomi Universitas Sriwijaya \\ Bukit Lama, Ilir Bar. I, Kota Palembang, Sumatera Selatan 30128 \\ *e-mail: marlinawidiyanti68@yahoo.co.id
}

\begin{abstract}
ABSTRAK
Penelitian ini bertujuan untuk mengetahui adakah pengaruh dari pasar modal syariah dalam pertumbuhan ekonomi di Indonesia. Penelitian ini menggunakan analisis deskriptif dengan melihat pertumbuhan dari Jakarta Islamic Index, Sukuk, dan Reksadana Syariah terhadap pertumbuhan ekonomi yang dihitung dari PDB di Indonesia dari Januari 2011 hingga Desember 2017. Hasil pembahasan secara deskriptif maka kesimpulan yang didapat bahwa dengan adanya pasar modal syariah di Indonesia, hal ini memberikan dampak positif untuk perkembangan pasar modal di Indonesia karena pasar modal syariah dapat menarik investor yang menginginkan investasi yang dijamin ke halalannya.
\end{abstract}

Kata Kunci: Instrumen Pasar Modal Syariah dan Pertumbuhan Ekonomi 


\begin{abstract}
This study aims to determine whether there is an influence from the Islamic capital market in economic growth in Indonesia. This study uses descriptive analysis by looking at the growth of the Jakarta Islamic Index, Sukuk, and Sharia Mutual Funds on economic growth calculated from GDP in Indonesia from January 2011 to December 2017. The results of the discussion are descriptive so the conclusions are obtained that the existence of the Islamic capital market in Indonesia This has a positive impact on the development of the capital market in Indonesia because the Islamic capital market can attract investors who want a guaranteed investment in their capital.
\end{abstract}

Keywords: Islamic Capital Market Instruments and Economic Growth

\title{
PENDAHULUAN
}

Keberhasilan pembangunan suatu negara dapat diukur dengan melihat indikator penting dari perkembangan pertumbuhan ekonomi sebagai proses peningkatan output dari waktu ke waktu (Todaro \& Smith, 2011). Salah satu hambatan utama bagi negara-negara yang sedang berkembang sebuah dalam pelaksanaan pembangunan ekonomi adalah ketersediaan modal yang terbatas.

Dalam meningkatkan kualitas perekonomian salah satu upaya yang dilakukan Indonesia adalah dengan menumbuhkan sektor investasi dengan menggunakan instrumen pasar modal (Shodiqurrosyad, 2014). Pasar modal adalah pasar keuangan yang sangat terspesialisasi dan terorganisir dan merupakan agen penting pertumbuhan ekonomi karena kemampuannya untuk memfasilitasi dan memobilisasi tabungan dan investasi (Nwaolisa, Kaise, \& Egbunike, 2013).

Berdasarkan ethical investment, ada beberapa investor yang mempunyai likuiditas dan selektif dalam memilih investasi, dalam memfasilitasi investor jenis ini, maka pasar modal melakukan penyesuaian yang dapat menampung seluruh jenis investor, salah satu alternatif dalam berinvestasi yaitu dengan adanya pasar modal syariah yang menggunakan prinsip-prinsip syariah (Susanto, 2009).

Pasar modal dengan prinsip-prinsip syariah merupakan komponen penting dari keseluruhan sistem keuangan syariah, meski telah menjadi pendatang akhir di industri ini, dimulai pada pertengahan tahun 1990-an. Khususnya, sektor ini telah mendapat momentum positif dan sekarang menarik beragam investor dan emiten dari seluruh dunia. Secara umum, pasar modal syariah terdiri dari tiga sektor utama pasar ekuitas syariah yang difasilitasi oleh indeks saham Syariah, Sukuk, dan pasar pendanaan Islam atau reksadana syariah (IFSB, 2015). 
Published July 2019

EKONOMIKAWAN : Jurnal Ilmu Ekonomi dan Studi Pembangunan

ISSN : 1693-7600 (Print), ISSN : 2598-0157 (Online), http://jurnal.umsu.ac.Id/index.php/ekawan

Pada 14 Maret 2003 secara resmi Indonesia meluncurkan pasar modal syariah bersamaan dengan penandatanganan Memorandum of Understanding (MoU) antara Badan Pengawas Pasar Modal-Lembaga Keuangan (Bapepam-LK) dengan Dewan Syariah Nasional-Majelis Ulama Indonesia (DSN- MUI) (Djamil, 2008). Namun, jauh sebelum 2003 kegiatan investasi syariah sudah ada pada 25 Juni 1997 dengan penerbitan Reksadana Syariah dan pada September awal tahun 2002 Indosat menerbitkan sukuk untuk jenis investasi lainnya (Soemitra, 2009). Selanjutnya Bursa Efek Indonesia bekerjsama dengan PT. Danareksa Investment Management pada 03 Juli 2000 meluncurkan Jakarta Islamic Index (JII) yang melisting 30 saham berbasis syariah (Soemitra, 2009).

Pasar modal syariah dalam perkembangannya terus mengalami peningkatan seiring dengan membaiknya perekonomian. Pasar modal syariah dapat dipengaruhi oleh indikator makro ekonomi yang terus mengalami perbaikan. Berdasarkan data dari OJK (Otoritas Jasa Keuangan), dapat dilihat pada tabel 1 bahwa terjadi peningkatan untuk jumlah emiten, saham yang diperdagangkan sukuk yang beredar, serta nilai aktiva bersih pada reksadana syariah. Berikut ini merupakan tabel investasi syariah dari tahun 2011 hingga 2017.

Tabel 1. Perkembangan Pasar Modal Syariah di Indonesia (Rp Miliar)

\begin{tabular}{rrrr}
\hline Tahun & $\begin{array}{c}\text { Sukuk } \\
\text { Korporasi }\end{array}$ & $\begin{array}{c}\text { Jakarta Islamic } \\
\text { Index }\end{array}$ & $\begin{array}{c}\text { Nilai Aktiva Bersih } \\
\text { Reksadana }\end{array}$ \\
\hline 2011 & 5991.42 & $1.414 .983,81$ & $5.564,79$ \\
2012 & 6146.83 & $1.671 .004,23$ & $8.050,07$ \\
2013 & 7343.92 & $1.672 .099,91$ & $9.432,19$ \\
2014 & 7062.92 & $1.944 .531,70$ & $11.158,00$ \\
2015 & 8804.50 & $1.737 .290,98$ & $11.019,43$ \\
2016 & 10598.75 & $2.041 .070,80$ & $14.914,63$ \\
2017 & 13618.44 & $2.288 .015,67$ & $28.311,77$ \\
\hline
\end{tabular}

Sumber: ojk.go.id, data diolah.

Pasar modal syariah memiliki tiga instrumen, salah satunya yang telah banyak diterbitkan oleh negara maupun korporasi adalah Obligasi Syariah atau Sukuk. Sukuk telah menjadi instrumen pembiayaan anggaran negara di beberapa negara yang telah menerbitkan sukuk. Beberapa negara saat ini yang telah menjadi regular issuer dari sukuk, misalnya Brunei Darussalam, Malaysia, Bahrain, Qatar, Uni Emirate, State of Saxony Anhalt-Jerman, dan Pakistan (Azwar, 2014).

Sukuk dapat memainkan peran penting dalam pembangunan ekonomi, dengan mempertahankan infrastruktur dan mode pembiayaan proyek praktis. Ini memastikan peluang pembiayaan yang berharga untuk menopang dan membiayai proyek pembangunan ekonomi. Pasar sukuk memenuhi peran yang sangat penting dalam mendanai proyekproyek besar dengan bertindak sebagai sumber penggalangan dana dan mempromosikan pasar modal lokal. Sukuk menjamin beberapa mekanisme alokasi aset yang tidak dapat disangkal, dan juga memelihara alat pengelolaan dana penting bagi perusahaan dan lembaga keuangan syariah (Saleem, Fakhfekh, \& Hachicha, 2016). 
Published July 2019

EKONOMIKAWAN : Jurnal Ilmu Ekonomi dan Studi Pembangunan

ISSN : 1693-7600 (Print), ISSN : 2598-0157 (Online), http://jurnal.umsu.ac.Id/index.php/ekawan

Di Indonesia, Sukuk juga diharapkan memiliki kontribusi dan sebagai sarana dalam pembangunan perekonomian negara. Setiap tahunnya perkembangan sukuk mengalami peningkatan dan dalam jangka panjang dianggap mampu memberikan kontribusi positif untuk pertumbuhan ekonomi. Selain sukuk instrumen pasar modal syariah lainnya adalah saham yang berprinsip syariah.

Saham Syariah yaitu bukti kepemilikan atas suatu perusahaan yang memenuhi prinsip syariah dan bukan saham yang memiliki hak-hak istimewa. Bagi investor yang memiliki preferensi berinvestasi pada instrumen penyertaan modal (ekuitas) maka penerbitan saham yang tidak bertentangan dengan prinsip syariah merupakan alternatif yang sangat menjanjikan (Soemitra, 2014). Terdapat dua jenis saham syariah di Indonesia, yaitu Jakarta Islamic Index (JII) dan Indeks Saham Syariah Indonesia (ISSI). Penelitian ini menggunakan indikator saham syariah dari kapitalisasi pasar JII.

Setiap tahunnya perkembangan Kapitalisasi pasar JII mengalami peningkatan secara signifikan, hal ini menunjukkan bahwa adanya kepercayaan investor yang terus tumbuh. Hal ini dapat menunjukkan bahwa adanya kemungkinan hubungan antara kondisi perekonomian yang dilihat dari pertumbuhan ekonomi dengan pasar modal syariah. Produk pasar modal syariah lainnya yang mampu mempengaruhi pertumbuhan ekonomi adalah reksadana syariah.

Reksadana syariah adalah wadah untuk menghimpun dana masyarakat yang dikelola oleh badan hukum yang bernama Manajer Investasi. Ada kesamaan pada profil keuntungan dan risiko investasi reksadana syariah dengan reksadana konvensional. Namun, keunikan reksadana syariah terletak pada pilihan portofolio efek yang sesuai dengan prinsip syariah, serta adanya proses pembersihan yang dilakukan oleh manajemen untuk mengeluarkan pendapatan nonhalal (Soemitra, 2014).

Kerangka teoritis mengenai efek pasar modal terhadap pertumbuhan ekonomi berawal dari hasil karya Schumpeter, (1911), yang menjelaskan bahwa sistem keuangan yang berkembang dengan baik dapat membantu investor untuk memperoleh layanan keuangan dan sumber daya melalui inovasi teknologi dan pertumbuhan ekonomi. Argumen di atas Schumpeter, (1911) kemudian dikembangkan sebagai hipotesis McKinnon-Shaw, (1973), yang merupakan alat analisis kebijakan untuk negara-negara berkembang dengan rekomendasi kuat dan prioritas tinggi pada efisiensi sistem keuangan dalam memfasilitasi akumulasi modal dan keuangan intermediasi (Yadirichukwu \& Chigbu, 2014).

Studi di berbagai negara mendukung bahwa pasar modal mampu mempengaruhi pertumbuhan ekonomi. Di Turki, Coskun et al., (2017) dan Bayar, Kaya, and Yildirim (2014) menyatakan bahwa ada hubungan jangka panjang antara pasar modal dan pertumbuhan ekonomi. Di Malaysia, Saleem, Fakhfeh, and Hachicha (2016) dan Nordin and Nordin (2016) menyatakan bahwa pasar modal mampu mempengaruhi pertumbuhan ekonomi. Di Nigeria, Edame and Okoro (2013) dan Yadirichukwu and Chigbu (2014) menyatakan bahwa pasar modal mampu mempengaruhi pertumbuhan ekonomi. 


\section{Published July 2019}

EKONOMIKAWAN : Jurnal Ilmu Ekonomi dan Studi Pembangunan

ISSN : 1693-7600 (Print), ISSN : 2598-0157 (Online), http://jurnal.umsu.ac.Id/index.php/ekawan

\section{KAJIAN TEORI}

\section{Pasar Modal Syariah}

Peran utama pasar modal adalah untuk mengumpulkan dana jangka panjang bagi pemerintah, bank, dan perusahaan sambil menyediakan platform untuk perdagangan sekuritas. Penggalangan dana ini diatur oleh kinerja pasar saham dan obligasi dalam pasar modal. Organisasi anggota pasar modal dapat menerbitkan saham dan obligasi untuk mengumpulkan dana. Investor kemudian dapat berinvestasi di pasar modal dengan membeli saham dan obligasi tersebut. Pasar modal, oleh karena itu, berfungsi sebagai penghubung antara penabung dan investor. Ini memainkan peran penting dalam memobilisasi tabungan dan mengalihkannya dalam investasi produktif. Dengan cara ini, pasar modal memainkan peran penting dalam mentransfer sumber daya keuangan dari area surplus dan boros ke area defisit dan produktif, sehingga meningkatkan produktivitas dan kemakmuran negara dan mendorong proses pertumbuhan ekonomi di negara tersebut (Siddique, 2012).

Pasar modal syariah adalah salah satu dari dua aspek penting dari Pasar Keuangan Islam yang lebih luas dan cabang lainnya merupakan Perbankan Islam dan Asuransi Islam yang lebih dikenal sebagai Takaful (Maiyaki, 2013). Pasar modal syariah mengacu pada pasar di mana kegiatan dilakukan dengan cara yang tidak bertentangan dengan prinsipprinsip Islam. Pasar modal syariah mewakili penegasan hukum agama dalam transaksi pasar modal di mana pasar bebas dari aktivitas dan elemen yang dilarang seperti riba (riba), maisir (judi), dan gharar (ambiguitas). Tumbuhnya kesadaran dan permintaan untuk berinvestasi sesuai dengan prinsip-prinsip Islam pada skala global telah menciptakan pasar modal syariah yang berkembang (Herzi, 2010).

\section{Instrumen Pasar Modal Syariah}

Instrumen pasar modal bentuknya beraneka ragam, pada prinsipnya pasar modal adalah semua surat-surat berharga (efek) yang diperdagangkan di bursa efek. Dalam pasar modal syariah instrumen yang boleh diperjualbelikan adalah instrumen pasar modal yang memenuhi prinsip-prinsip Islam, adapun yang menjadi instrumen pasar modal syariah adalah:

\section{a. Saham Syariah}

Saham syariah adalah saham yang tidak bertentangan dengan prinsip-prinsip Islam di pasar modal. Bursa saham Islami harus diatur berdasarkan prinsip islam melalui partisipasi ekuitas. Kepemilikan bursa saham akan menjadi milik pemegang saham di bursa saham. Untuk mencapai berfungsinya bursa efek, pemegang sahamnya tidak akan diizinkan untuk berpartisipasi dalam perdagangan dan tidak akan diizinkan menjadi mitra pemain lain di pasar saham. Pemegang saham ini dapat berupa institusi maupun individu. Para pemegang saham harus mematuhi semua hukum berdasarkan syariah. Bursa saham akan dikenakan tata kelola perusahaan berdasarkan ketentuan Islam atau kode Islam (Khan, 2010). 
Published July 2019

EKONOMIKAWAN : Jurnal Ilmu Ekonomi dan Studi Pembangunan

ISSN : 1693-7600 (Print), ISSN : 2598-0157 (Online), http://jurnal.umsu.ac.Id/index.php/ekawan

\section{b. Sukuk}

Sukuk (surat berharga syariah) dianggap sebagai instrumen keuangan syariah yang dibuat untuk pembiayaan jangka menengah dan panjang karena beberapa keterbatasan yang ada dalam sistem keuangan syariah, sehingga kurangnya penggunaan obligasi umum. Instrumen ini sangat mirip dengan obligasi biasa; Namun, ada beberapa perbedaan juga antara keduanya dan dalam beberapa kasus mereka menanggung karakteristik saham. Hal ini menyebabkan Sukuk dianggap sebagai jenis instrumen keuangan hybrid. Di luar sistem keuangan Islam, instrumen hybrid dianggap sebagai salah satu jenis sekuritas yang berlaku dan umum. Instrumen ini dibagi menjadi beberapa kategori, yang masing-masing memiliki karakteristik obligasi dan saham (Zolfaghari, 2017).

\section{c. Reksadana Syariah}

Reksa Dana Syariah adalah dana investasi yang diatur oleh persyaratan hukum Syariah dan prinsip-prinsip agama Islam. Dana yang sesuai syariah dianggap sebagai jenis investasi yang bertanggung jawab secara social Dana yang sesuai syariah memiliki banyak persyaratan yang harus dipatuhi. Beberapa persyaratan untuk dana yang sesuai syariah termasuk pengecualian investasi yang memperoleh sebagian besar pendapatan mereka dari penjualan alkohol, produk daging babi, pornografi, perjudian, peralatan militer atau senjata. Karakteristik lain dari dana yang sesuai Syariah termasuk dewan Syariah yang ditunjuk, audit Syariah tahunan dan memurnikan jenis pendapatan tertentu yang dilarang, seperti bunga, dengan menyumbangkannya untuk amal (Chen, 2019).

\section{Konsep Pertumbuhan Ekonomi}

Pertumbuhan ekonomi, indikator kesejahteraan suatu negara, diukur dengan GNP atau nilai per kapita. Dalam sebagian besar buku ekonomi makro, konsep pertumbuhan ekonomi didefinisikan sebagai peningkatan dalam jumlah barang dan jasa yang diproduksi di suatu negara selama saat kemajuan ((Soylu, Cakmak, \& Okur, 2018).

Dalam penelitian ini untuk melihat kemajuan perekonomian di Indonesia indikator yang digunakan adalah konsep pertumbuhan ekonomi yang diukur dari Produk Domestik Bruto.

\section{METODE}

Adapun metode pembahasan dalam tulisan ini adalah studi analisis kepustakaan dengan teknik analisis deskriptif. Teknik analisis deskriptif merupakan teknik penelitian dengan mengumpulkan data berupa tulisan-tulisan dari penelitian terdahulu dan disusun untuk melihat hasil dari data yang sudah dikumpulkan, teknik ini tidak menggunakan angka-angka untuk pengujian statistik atau asumsi klasik.

\section{HASIL DAN PEMBAHASAN}

\section{Pembahasan Pertumbuhan ekonomi di Indonesia}

Pengukuran dalam perekonomian di Indonesia dilihat dari Produk Domestik Bruto (PDB), dan setelah itu dihitung dengan rumus pertumbuhan untuk melihat berapa persen pertumbuhan ekonomi yang terjadi setiap tahunnya. Pertumbuhan ekonomi merupakan sebuah perubahan output yang dihasilkan oleh suatu perekonomian pada periode tertentu. 
Berikut ini gambar 1, grafik dari pertumbuhan ekonomi di Indonesia tahun 2011 hingga 2017.

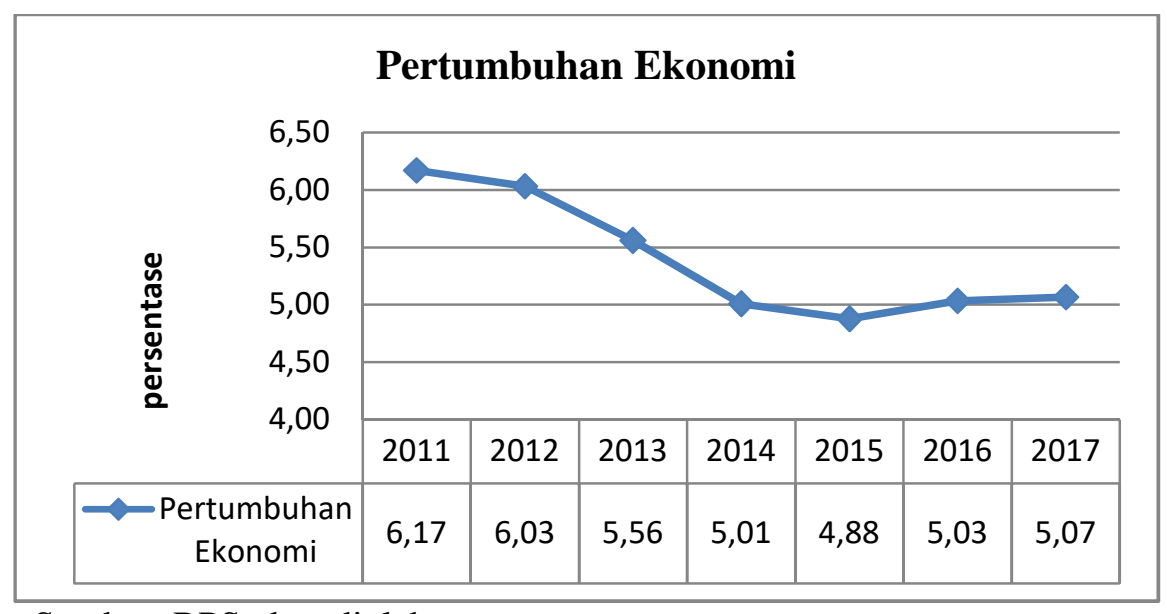

Sumber: BPS, data diolah

Gambar 1. Grafik Pertumbuhan ekonomi di Indonesia

Pada Gambar 1 dapat dilihat bahwa tahun 2011, pertumbuhan ekonomi di Indonesia mengalami pertumbuhan sebesar 6,17\% hingga tahun 2013 melambat hanya sebesar 5,56\%. Pada tahun 2013 pertumbuhan ekonomi melambat dikarenakan oleh perekonomian global yang tidak pasti dan adanya isu finansial seperti defisit transaksi berjalan, inflasi yang tinggi (kenaikan harga BBM bersubsidi pada Juni 2013) dan nilai tukar rupiah yang melemah. Secara umum, pada tahun 2014 pertumbuhan ekonomi kembali mengalami kelambatan dan hanya mampu tumbuh sebesar 5,01\%. Bahkan angka ini lebih rendah dibandingkan target yang telah ditetapkan oleh pemerintah dalam Anggaran Pendapatan dan Belanja Negara Perubahan (APBN-P) 2014 sebesar 5,5 persen. Faktor eksternal dan internal menjadi penyebab terjadinya perlambatan ekonomi tersebut. Faktor eksternal yang terjadi berupa penurunan ekspor sebagai akibat dari penurunan permintaan dan harga komoditas global. Sementara itu, dari faktor internal terjadi perlambatan ekonomi disebabkan terbatasnya konsumsi pemerintah sebagai dampak dari program penghematan anggaran. Pertumbuhan ekonomi yang masih cukup tinggi ditopang oleh konsumsi rumah tangga yang tetap solid.

Perkembangan menunjukkan pertumbuhan ekonomi yang terus membaik secara perlahan sehingga PDB pada 2017 tercatat tumbuh 5,07\%, meningkat dibandingkan dengan pertumbuhan ekonomi tahun sebelumnya sebesar 5,03\%. Dinamika tersebut ditopang pergerakan ekspor dan investasi yang pada 2017 membaik sejalan kondisi global yang kondusif dan stabilitas ekonomi domestik yang terjaga baik. Peran ekspor dan investasi yang menguat juga tergambar pada kontribusi kedua komponen tersebut terhadap pertumbuhan ekonomi yang meningkat bila dibandingkan dengan tahun 2016. 
Published July 2019

EKONOMIKAWAN : Jurnal Ilmu Ekonomi dan Studi Pembangunan

ISSN : 1693-7600 (Print), ISSN : 2598-0157 (Online), http://jurnal.umsu.ac.Id/index.php/ekawan

\section{Kontribusi Pasar Modal Syariah terhadap Pertumbuhan ekonomi di Indonesia}

Pasar modal syariah adalah suatu kegiatan pasar modal dimana menggunakan karakteristik. Adapun karakteristik tersebut merupakan adanya proses pengelolaan baik dari menciptakan produk membuat kontrak dalam penerbitan efek syariah, melakukan transaksi perdagangan, serta melakukan aktivitas pasar modal lainnya dengan menggunakan prinsip-prinsip syariah dan diawasi oleh Dewan Syariah Nasional (DSN). Prinsip-prinsip syariah tersebut harus menghindari dari unsur perjudian (maysir), ketidakpastian (gharar), sistem bunga (riba), dan ketidakadilan.

Peran Pasar Modal Syariah (PMS) dapat mempengaruhi Pertumbuhan Ekonomi (PE) di Indonesia terlihat dengan perkembangan pasar modal syariah akan berpengaruh pada indikator-indikator ekonomi seperti nilai tukar riil, tingkat inflasi, dan juga produk domestik bruto yang menjadi tolak ukur pertumbuhan ekonomi. Berikut ini grafik kontribusi pasar modal syariah terhadap pertumbuhan ekonomi dari tahun 2012 hingga 2017.

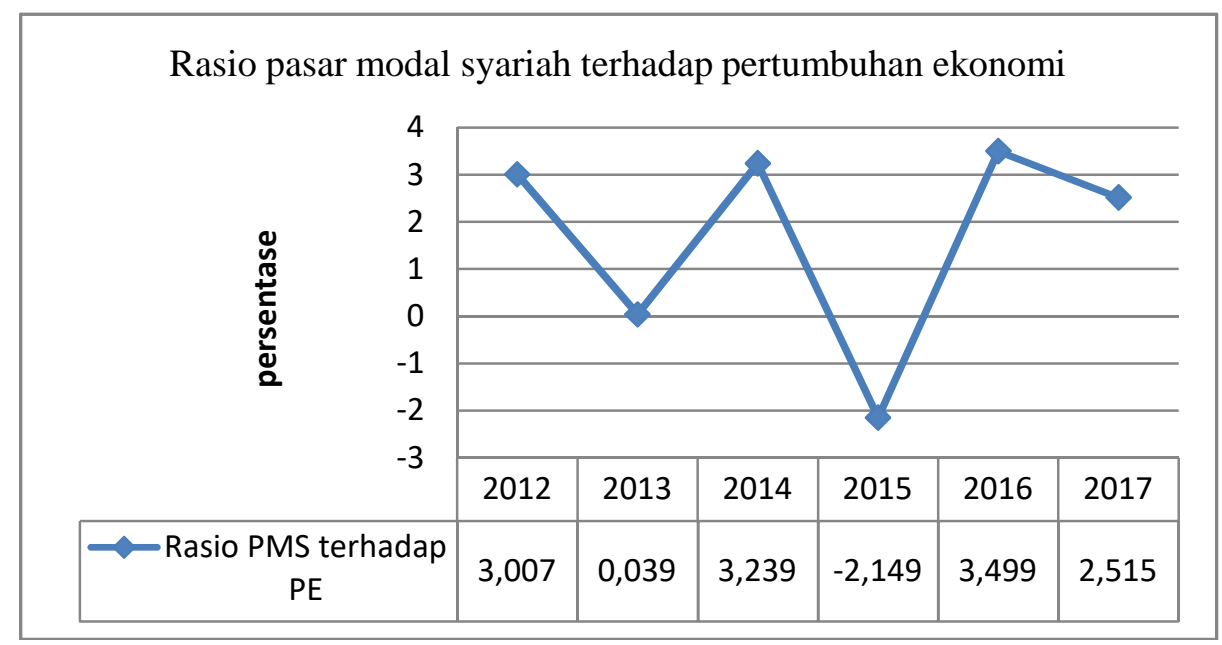

Gambar 2. Rasio Pasar Modal Syariah Terhadap Pertumbuhan Ekonomi

Pada grafik dapat dilihat pergerakan kontribusi pasar modal syariah (PMS) terhadap pertumbuhan ekonomi (PE) yang tidak stabil, pada tahun 2013 kontribusi PMS terhadap PE mengalami penurunan dari 3,007 persen menjadi 0,039 persen. Hal ini dikarenakan bergesernya faktor-faktor global yang sebelumnya menguntungkan perekonomian di Indonesia. Pada tahun 2013 terjadi perlambatan pertumbuhan ekonomi negara-negara emerging market seperti China India menimbulkan dampak pada berakhirnya era harga komoditas yang tinggi, sehingga menurunkan terms of trade Indonesia dan akhirnya menekan kinerja ekspor komoditas primer. Lemahnya kinerja ekspor ini menaikkan defisit transaksi berjalan.

Tahun 2014 kontribusi PMS terhadap PE kembali meningkat hingga 3,239 persen, hal ini dikarenakan terjadinya pemulihan pada perokonomian global, namun kondisi ekonomi masih dalam kategori lemah, terlihat dari penurunan harga komoditas non migas dan harga minyak. 
Namun, pada tahun 2015 perekonomian di Indonesia mengalami tantangan dikarenakan kondisi perekonomian diliput gejolak, baik yang bersumber dari perekonomian dunia atau global maupun di dalam negeri atau domestik. Lemahnya pemulihan ekonomi global menyebabkan berlanjutnya harga komoditas yang menurun dan aliran modal asing ke negara berkembangpun mengalami penurunan, hal ini menjadi pemicu tekanan terhadap perekonomian di Indonesia yang termasuk dalam negara yang sedang berkembang. Hal ini terlihat juga pada kontribusi pasar modal syariah terhadap pertumbuhan ekonomi yang mengalami penurunan hingga minus 2,149 persen.

Tahun 2016 kontribusi pasar modal syariah terhadap pertumbuhan ekonomi kembali meningkat hingga sebesar 3.499 persen. Hal ini dikarenakan sinergi dan konsistensi kebijakan yang ditempuh oleh Bank Indonesia dan pemerintah untuk menjaga stabilitas makro ekonomi sambil mendorong momentum pertumbuhan mampu membawa perekonomian Indonesia keluar dari berbagai tekanan eksternal dengan tetap berada pada jalur kesinambungan yang benar.

Tahun 2017 kontribusi pasar modal syariah terhadap pertumbuhan ekonomi mengalami penurunan hanya saja tidak terlalu besar seperti tahun 2013 dan 2015. Hal ini dikarenakan terjadi penurunan pasar modal syariah di Indonesia sehingga untuk kontribusi terhadap pertumbuhan ekonomi juga mengalami penurunan.

Perkembangan pasar modal syariah yang dari tahun ke tahun terus menunjukkan peningkatan berdampak baik terhadap pertumbuhan ekonomi. Ini sesuai dengan teori pertumbuhan ekonomi Shumpeter yang menyatakan bahwa perkembangan ekonomi disebabkan oleh faktor utama yaitu proses inovasi dan pelakunya adalah para investor atau wiraswastawan. Kemajuan ekonomi suatu masyarakat hanya bisa diterapkan dengan adanya inovasi oleh para wiraswasta. Dengan adanya inovasi tersebut dan didorong oleh keinginan untuk memperoleh keuntungan maka akan diadakan penanaman modal baru. Investasi yang baru ini akan meningkatkan kegiatan ekonomi. Pendapatan masyarakat akan bertambah dan tingkat konsumsi menjadi bertambah tinggi. Kenaikan tersebut akan mendorong perusahaan-perusahaan lain untuk menghasilkan lebih banyak barang dan melakukan penanaman modal baru.

\section{SIMPULAN}

Berdasarkan hasil pembahasan secara deskriptif maka kesimpulan yang didapat bahwa dengan adanya pasar modal syariah di Indonesia, hal ini memberikan dampak positif untuk perkembangan pasar modal di Indonesia karena pasar modal syariah dapat menarik investor yang menginginkan investasi yang dijamin ke halalannya. Dengan berkembangnya pasar modal syariah dari tahun ke tahun terbukti bahwa pasar modal syariah semakin diminati baik dari investor muslim atau non muslim, hal ini dapat membuat pasar modal syariah berkontribusi terhadap pertumbuhan ekonomi di Indonesia.

\section{DAFTAR PUSTAKA}

Azwar. (2014). Pengaruh Penerbitan Sukuk Negara Sebagai Pembiayaan Defisit Fiskal dan Kondisi Ekonomi Makro Terhadap Perkembangan Perbankan Syariah Di Indonesia. Jurnal Of Info Artha Sekolah Tinggi Akuntansi Negara (Stan), Ii(Xii), 1-21.

$\begin{array}{cccc}\text { Chen, J. (2019). Shariah-Compliant Funds. } & \text { Retrieved } & \text { from } \\ \text { https://www.investopedia.com/terms/s/shariah-compliant-funds.asp } & & \end{array}$ 
Published July 2019

EKONOMIKAWAN : Jurnal Ilmu Ekonomi dan Studi Pembangunan

ISSN : 1693-7600 (Print), ISSN : 2598-0157 (Online), http://jurnal.umsu.ac.Id/index.php/ekawan

Djamil, F. (2008). Seminar Nationalon Performance and Prospect of Indonesian Islamic Capital Market. In Prospek Pasar Modal Syariah Indonesia. Jakarta: STIE Ahmad Dahlan.

Herzi, A. A. (2010). An overview of Islamic Capital Market in Malaysia. Malaysia.

IFSB. (2015). Islamic Financial Service Industry: Stability Report 2015, Islamic Financial Service Board.

Khan, M. . (2010). Stocks Market in Islamic Frame Work. Retrieved from http://pragmaticwealth.net/KnowledgeCentre/PDF/Stocks Market in Islamic Frame Work.pdf

Maiyaki, A. A. (2013). Principles of Islamic Capital Market. International Journal of Academic Research in Accounting, Finance and Management Sciences, 3(4), 278-283.

Nwaolisa, E. F., Kaise, E. G., \& Egbunike, C. F. (2013). The Impact of Capital Market on The Growth of The Nigerian Economy Under Democratic Rule. Arabian Journal of Business and Management Review (OMAN Chapter), 3(2).

Saleem, M. Ben, Fakhfekh, M., \& Hachicha, N. (2016). Sukuk Issuance and Economic Growth: The Malaysian Case. Journal of Islamic Economics, Banking and Finance, 12(2).

Shodiqurrosyad, A. (2014). Peran Pasar Modal Syariah terhadap Pertumbuhan Ekonomi Indonesia. UIN Sunan Ampel, Surabaya.

Siddique, A. H. (2012). Capital Markets. In Pakistan Economic Survey 2012-13 (pp. 77-90). Pakistan.

Soemitra, A. (2009). Bank dan Lembaga Keuangan Syariah. Jakarta: Kencana.

Soemitra, A. (2014). Masa Depan Pasar Modal Syariah di Indonesia. Jakarta: Kencana.

Soylu, O. B., Cakmak, I., \& Okur, F. (2018). Economic Growth and Unemployment Issue: Panel Data Analysis in Eastern European Countries. Journal of International Studies, 11(1), 93107. https://doi.org/10.14252/2071-8330.2018/11-1/7

Susanto, B. (2009). Pasar Modal Syariah: Tinjauan Hukum. Yogyakarta: UII Press.

Todaro, M. P., \& Smith, S. C. (2011). Economic Development. UK: Pearson Education Limited.

Yadirichukwu, E., \& Chigbu, E. E. (2014). The impact of capital market on economic growth: the Nigerian perspective. International Journal of Development and Sustainability.

Zolfaghari, P. (2017). An Introduction to Islamic Securities (Sukuk). Iran. 